\title{
Üniversite Öğrencilerinin Finansal Okuryazarlık Düzeylerinin Tespit Edilmesi: Adnan Menderes Üniversitesi iiB
}

\author{
Determining the Financial Literacy Levels of University Students: The Example of Adnan \\ Menderes University FEAS Students
}

\author{
Bilgehan TEKIN² \\ Vedat DURSUN ${ }^{3}$
}

\begin{abstract}
öz
Bu çalışmanın amacı, iktisadi ve İdari Bilimler Fakültesi'nde öğrenim gören öğrencilerin finansal okuryazarlık bilgi, tutum ve davranış düzeylerinin incelenmesidir. Çalışmanın örneklemini Adnan Menderes Üniversitesi Nazilli iktisadi ve ídari Bilimler Fakültesi'nin farklı bölümlerinde öğrenim gören öğrenciler oluşturmuştur. Anket ile toplanan verilerin analizinde frekans analizleri, faktör analizi, bağımsız gruplar t testi, ANOVA analizi ve Ki-Kare testi kullanılmıştır. Çalışmada üç farklı finansal okuryazarlık ölçeğ kullanılmıştır. Her bir ölçekle toplanan veriler kendi içerisinde analiz edilmiş, değerlendirilmiş ve yorumlanmıştır. Çalışma sonucunda finansal okuryazarlık alt ölçekleri ile cinsiyet arasında belirli düzeyde anlamlı ilişki olduğu, ebeveynlerin eğitim düzeyleri ile öğrencilerin finansal okuryazarlık düzeyleri arasında bir ilişki olmadığı, öğrenciler tarafından en fazla bilinen temel finansa kavramların sırasıyla risk-getiri oranları, hazine bonosu ve ek limit ve faiz oranları olduğu, cinsiyet ve bölüm ile finansal kavramların bilinirlik düzeyleri arasında belirli düzeylerde ilişki olduğu tespit edilmiştir.
\end{abstract}

Anahtar Kelimeler: Finansal Okuryazarlık, Üniversite Öğrencileri, ANOVA Testi.

\section{ABSTRACT}

The aim of this study is to examine the financial literacy levels of knowledge, attitudes and behavior of the students who are receiving education at the Faculty of Economics and Administrative Sciences. The sample of the study constituted of who receive education in different departments of the Nazilli Faculty of Economics and Administrative Sciences of Adnan Menderes University. Frequency analysis, factor analysis, independent groups $t$ test, Anova analysis and Chi-Square test were used in the analysis of the data collected by the questionnaire. Three different financial literacy scales were used in the study. The data collected with each scale were analyzed, evaluated and interpreted. As a result of the study, there is a significant relationship between financia literacy subscales and gender, there is no relationship between parents 'education levels and students' financial literacy levels. It is determined that there is a certain level of relationship between gender and department and awareness levels of financial concepts.

Keywords: Financial Literacy, University Students, ANOVA Test

${ }^{1}$ Bu çalışma Vedat Dursun tarafından Doç.Dr. Bilgehan TEKiN danışmanlı̆ı̆ında hazırlanan "Üniversite öğrencilerinin finansal okuryazarlık bilgi, tutum ve davranış düzeylerinin araştıııması: Adnan Menderes Üniversitesi Örneği" başlıklı tezden üretilmiştir.

2Doç.Dr., Çankırı Karatekin Üniversitesi İktisadi ve İdari Bilimler Fakültesi İsletme Bölümü, btekin@karatekin.edu.tr, (ORCID: 0000-0002-4926-3317)

${ }^{3}$ Yüksek Lisans Öğrencisi, Çankırı Karatekin Üniversitesi Sosyal Bilimler Enstitüsü, vedatdursun0009@outlook.com, (ORCID: 0000-0000-0010-0033) 


\section{Giriş}

Günümüzde anlaşılması daha da karmaşık hale gelen ekonomik sistem ve finansal piyasalar ile ilgili kavramlar genç nüfusun finansal okuryazarlık düzeylerini de etkilemektedir. Bu durum, politika yapıcıların genç nüfusun ekonomi ve finans alanları ile ilgili bilgi düzeylerini yükseltmeye yönelik yeni ve farklı politikalar geliştirmelerini zorunlu hale getirmektedir (Kılıç, Ata ve Seyrek, 2015, s. 130).

Yetersiz finansal bilgi düzeyi bireylerin finansal karar süreçlerinde önemli hatalar yapmalarına neden olan bir unsurdur. Finansal okuryazarlık, bireylerin finansal piyasalardaki riski anlamalarına ve strateji geliştirmelerine, piyasalardaki firsatları görebilmelerine ve tasarruflarını bilinçli bir şekilde yapabilmelerine imkan tanımaktadır. Finansal okuryazarlık düzeyi, bireylerin geleceğini de etkilemektedir. Bireylerin emeklilik dönemlerinde yeterli bir ekonomik refah seviyesinde yaşamlarını sürdürebilmeleri, çalışma hayatı dönemlerinde gerçekleştirdikleri yatırımlardan doğrudan etkilenmektedir (Altıntaş, 2009, s. 152). Diğer yandan Türkiye gibi genç nüfusun yoğun olduğu ülkelerde genç nüfusun finansal okuryazarlık düzeylerinin tespit edilmesine ve artırılmasına yönelik uygulanacak politikalar, gelecekte yaşanabilecek ve toplumun geneli ile ülke ekonomisine etki eden geniş çaplı problemleri önlemek için oldukça önemlidir (K1lıç vd., 2015, s. 132-133).

Finansal okuryazarlık konusu finansal sorumluluk ile birlikte değerlendirilmelidir. Finansal sorumluluk, sadece bireyin kendi geleceği için değil aynı zamanda toplumun geleceğini de etkileyen finansal kararları alabilme yetisidir. Alınan finansal kararlar ile sadece kişinin kendi geleceği değil, ailesinin ve toplumun da geleceğinin etkilenmesi söz konusudur (Mason, 2003, s. 59-61). Bu açıdan bakıldı̆̆ında, bireylerin finansal boyutu olan kararlarında, finansal sorumluluklarını hem ailevi hem de toplumsal açıdan değerlendirmesi gerekmektedir. Bireyin finansal sorumluluklarının farkında olması ve ona göre davranışlarını şekillendirmesi ise ancak finansal okuryazarlık seviyesinin yükseltilmesi ile sağlanabilir.

$\mathrm{Bu}$ bağlamda çalışmanın amacı, genç nüfusu temsil eden üniversite öğrencilerinin finansal okuryazarlık bilgi, tutum ve davranış düzeylerinin tespit edilmesi ve çeşitli demografik özellikleri ile karşılaştırılarak çıkarımda bulunulmasıdır. Çalışmanın örneklemini 2018-2019 eğitim-öğretim yılında Adnan Menderes Üniversitesi Nazilli İktisadi ve İdari Bilimler Fakültesi’nin farklı bölümlerinde öğrenim gören öğrenciler oluşturmuştur. Çalışmada anket yöntemi ile veriler toplanmıştır. Toplanan verilerin analizinde frekans analizleri, faktör analizi, bağımsız gruplar t testi, ANOVA analizi ve Ki-Kare testi kullanılmıştır.

\section{Kavramsal Çerçeve}

Türkiye Bankalar Birliği (TBB) finansal okuryazarlığı; "bireylerin bütçe yapma, tasarruf, borç alma ve yatırım gibi anahtar finansal kavramlar hakkında bilgi sahibi olmaları ve bu bilgileri kararlarında kullanabilme becerisidir" şeklinde tanımlamaktadır. 
TBB finansal okuryazarlığın 3 temel boyutundan bahsetmektedir. Bunlar finansal bilgi, finansal tutum ve finansal davranıştır.

Finansal Bilgi: Bireylerin bütçe, sigorta, tasarruf, yatırım, kredi, basit ve bileşik faiz, enflasyon, risk, getiri, vade, varlık, borç gibi temel finans kavramları bilmesidir.

Finansal Tutum/Tavır: Bireylerin, parayı dikkatli kullanma, idareli tüketme, gelecek için birikim yapma gibi konularda daha önce yaşadığı çeşitli deneyimler sonucu düzenli bir finansal tavir sergilemeleridir.

Finansal Davranış: Bireylerin, kişisel bütçelerini izlemeleri, dikkatli alışveriş̧ yapmaları, birikimlerini, tasarruflarını ve yatırımlarını, kişisel borç ve kredilerini yönetebilmeleri, kısa ve uzun vadede yatırımlarını değerlendirebilmeleridir.

Gelişmekte olan ülkelerdeki en önemli problemlerden biri bireylerin finansal okuryazarlık düzeylerinin istenen seviyelerde olmamasıdır. Bu nedenle Türkiye'de sürekli olarak gündemde kalmaktadır. OECD (2016) tarafından yapılan çalışmada Türkiye, finansal bilgi, finansal davranış ve finansal tutum düzeyi genel ortalama skorunda ankete katılan 30 ülke arasında 21. sırada, ankete katılan 17 OECD üyesi ülke arasinda da 15 . siradadir.

Toplumların finansal okuryazarlık düzeylerinin arttırılmasının ve verdikleri kararların daha bilinçli verilebilmesinin yolu iyi bir finansal eğitim almalarından geçmektedir. Finansal eğitimle birey tasarruf, yatırım, borç ve kredi yönetiminin yanı sıra finansal dolandırıcılıktan korunma yöntemlerini, karşılaşacağı hukuksal problemlerde nasıl bir yol izleyeceğini, sahip olduğu hakları ve bu hakların kullanım yollarını öğrenmektedir (TBB, Erişim:25.08.2019). TBB tarafından kendi internet sitelerinde yer alan ve Willis (2008) tarafından yapılan çalışmadan alıntılanan finansal eğitim diyagramı ise şöyledir:

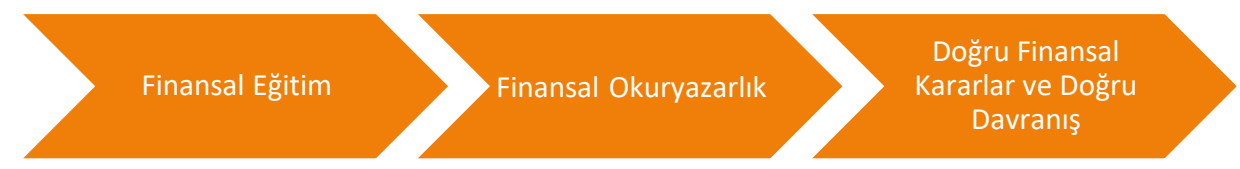

Şekil 1: Finansal Eğitim Diyagramı

Kaynak: Willis L. E. 2008

Diyagrama göre ilk aşama finansal eğitimdir. Finansal eğitimi olması gerektiği gibi alan bireyler finansal okuryazarlık seviyelerini arttıracak ve en doğru finansal yatırım veya borçlanma kararlarını rahatlıkla verebileceklerdir.

Her birey parayı etkili ve verimli kullanabilme yetisine sahip olmak ister. Bireylerin içinde yaşadığı ekonomik ve finansal sistemi daha kolay anlamasını sağlayan finansal okuryazarlık, kişileri daha rasyonel ve girişken davranmaya ve ekonomik problemleri ve çözümlerini daha iyi anlamalarına yardımcı olur (Gerek ve Kurt, 2011, s. 61). 
Finansal okuryazarlık genel olarak finansal piyasa ürünlerinin risk ve karmaşık yapılarının daha iyi anlaşılması ve bunlara aşinalık sağlanması olarak da tanımlanabilir. Sahip oldukları imkanlar ölçüsünde yaşamak zorunda kalan kişilerin, doğru finansal kararlar verebilmeleri, yeterli finansal bilgiye sahip olmalarına ve bu bilgi sayesinde finansal sorunlarla etkin mücadele edebilmelerine bağlıdır. Finansal bilgi seviyesi yüksek bireyler gelecek planlamalarında daha başarılı olacak, borçlarını daha rahat yönetebilirken, gelir ve giderlerini daha etkin kontrol edebileceklerdir (Chinen ve Endo, 2012, s. 33-36).

Finansal okuryazarlık aynı zamanda bireyin parasal refahını etkileyen finansal koşulları anlama, yorumlama, idare etme ve yazma yeteneğidir. Bu, finansal seçenekleri ayırt etme, parasal ve finansal konuları tartışma, gelecek için plan yapma ve gündelik finansal kararları etkileyen hayatın doğal akışı içerisindeki olaylara etkin bir biçimde yanıt verme gibi etkinlikleri de içermektedir (Vitt vd., 2005, s. 7-9).

Bu çalışmada yukarıdaki olgulardan hareketle Türkiye'nin eğitimli genç nüfusunun önemli bir örneğini teşkil eden üniversite öğrencilerinin finansal okuryazarlık düzeylerinin ölçülmesi amaçlanmıştır. Bu amaç doğrultusunda Adnan Menderes Üniversitesi İktisadi ve İdari Bilimler Fakültesi öğrencileri örneklem olarak seçilmiştir. Örneklem üzerinden anket uygulaması ile veri toplanmıştır. Çalışmanın analiz aşamasında frekans analizleri, tanımlayıcı analizler, faktör analizleri, bağımsız gruplar $\mathrm{t}$ testi, ANOVA, Ki-Kare bağımsızlık testi yöntemleri kullanılmıştır.

\section{Literatür}

Akademik anlamda yapılan çalışmalar incelendiğinde birçok araştırmacının ilgisini çektiği tespit edilen finansal okuryazarlık konusunun toplumun farklı kesimleri üzerinden incelendiği görülmektedir. Finansal okuryazarlık özellikle üniversiteden sonra farklı alanlarda iş hayatına atılacak olan öğrenciler için ise ayrıca önemli bir konudur. Bireylerin finansal okuryazarlık düzeyinin yükseltilebilmesi için belki de ilk adım mevcut finansal okuryazarlık düzeylerinin belirlenmesidir (Temizel, 2010: 91-96; Cihangir ve Ergin, 2015: 131-136). Bu bağlamda, toplumların farklı kesimlerinin finansal okuryazarlık düzeylerinin tespit edilmesine yönelik daha önce yapılan çalışmaların bir özeti aşağıda verilmiştir:

Tablo 1: Literatür Özeti

\begin{tabular}{|c|c|l|}
\hline Yazar(lar) & \multicolumn{1}{|c|}{ Örneklem } & \multicolumn{1}{c|}{ Sonuç } \\
\hline Volbe vd. (1996) & Üniversite Öğrencileri & $\begin{array}{l}\text { İktisadi ve İdari Bilimler Fakültesi’nde } \\
\text { eğitim alan öğrencilerin diğer fakültelerde } \\
\text { eğitim alan öğrencilere göre finansal yatırım } \\
\text { düzeylerinde artış gösterdiklerini tespit } \\
\text { etmişlerdir. }\end{array}$ \\
\hline
\end{tabular}


Üniversite Öğrencilerinin Finansal Okuryazarlık Düzeylerinin Tespit Edilmesi: Adnan Menderes Üniversitesi iiBF Öğrencileri Örneği

\begin{tabular}{|c|c|c|}
\hline $\begin{array}{l}\text { Chen ve Volpe } \\
\text { (1998) }\end{array}$ & Üniversite öğrencileri & $\begin{array}{l}\text { Öğrencilerin finansal bilgi, tutum ve } \\
\text { davranış seviyelerinin düşük ve finansal } \\
\text { karar verme becerilerinin de sinırlı olduğu } \\
\text { belirtilmiştir }\end{array}$ \\
\hline $\begin{array}{l}\text { Hilgert ve diğerleri } \\
\qquad(2003)\end{array}$ & Hane halkları & $\begin{array}{l}\text { Finansal bilgi düzeyleri yüksek olan } \\
\text { bireylerin finansal davranış düzeylerinin de } \\
\text { yüksek olduğunu saptamıstır. }\end{array}$ \\
\hline $\begin{array}{l}\text { Clark ve diğerleri } \\
\qquad(2003)\end{array}$ & $\begin{array}{l}\text { Finans Semineri } \\
\text { Katılımciları }\end{array}$ & $\begin{array}{l}\text { Finansal eğitim alan bireylerin daha etkin } \\
\text { finansal tasarruf planlaması yaptığı tespit } \\
\text { edilmiştir. }\end{array}$ \\
\hline $\begin{array}{l}\text { Varcoe ve diğerleri } \\
\qquad(2005)\end{array}$ & Öğrenciler & $\begin{array}{l}\text { Finans dersi alan öğrencilerin finansal } \\
\text { okuryazarlık düzeylerinin arttı̆̆ ve finansal } \\
\text { davranışlarının da olumlu yönde değiştiği } \\
\text { saptanmıştır. }\end{array}$ \\
\hline $\begin{array}{l}\text { Lusardi ve Mitchell } \\
\text { (2006) }\end{array}$ & ABD'de katılımcılar & $\begin{array}{l}\text { Finansal bilgi düzeyi arttıkça finansal } \\
\text { planlama oranının da arttığ saptanmıştır. }\end{array}$ \\
\hline Kieschnick (2006) & Lise öğrencileri & $\begin{array}{l}\text { Finansal bilgi düzeyleri yüksek olan } \\
\text { öğrencilerin tasarruf davranışlarının da } \\
\text { olumlu yönde değiştiği ve bu öğrencilerin } \\
\text { birçoğunun düzenli olarak tasarruf yaptıkları } \\
\text { tespit edilmiştir. }\end{array}$ \\
\hline $\begin{array}{l}\text { Volpe ve diğerleri } \\
\text { (2006) }\end{array}$ & Çalışan yetişkinler & $\begin{array}{l}\text { Katılımcıların finansal bilgi düzeylerinin } \\
\text { düşük olduğu belirlenmiştir. }\end{array}$ \\
\hline Jorgensen (2007) & Üniversite Öğrencileri & $\begin{array}{lcr}\text { Öğrencilerin } & \text { finansal } & \text { okuryazarlık } \\
\text { puanlarının düşük olduğu, ama eğitim } \\
\text { seviyesinin } \\
\text { okuryazarlı ögrencilerin } & \text { düzeyi üzerinde } & \text { flumansal } \\
\text { olduğu saptanmıştır. } & \end{array}$ \\
\hline $\begin{array}{l}\text { Mandell ve Klein } \\
(2007)\end{array}$ & Genç nüfus & $\begin{array}{l}\text { Gençlerin finansal bilgi seviyelerinin düşük } \\
\text { olduğu sonucuna ulaşılmıştır. }\end{array}$ \\
\hline $\begin{array}{l}\text { Rooij ve diğerleri } \\
(2007)\end{array}$ & Hane halk1 & $\begin{array}{l}\text { Finansal eğitimle finansal okuryazarlık } \\
\text { arasında doğru orantı olduğu saptanmıştır. }\end{array}$ \\
\hline $\begin{array}{l}\text { Mandell ve Klein } \\
\text { (2009) }\end{array}$ & Lise öğrencileri & $\begin{array}{l}\text { Finans eğitimi almış kişilerin finansal bilgi } \\
\text { düzeylerinde artış gösterdikleri ve finansal } \\
\text { kararları daha etkili şekilde verdikleri } \\
\text { belirtilmiştir. }\end{array}$ \\
\hline $\begin{array}{l}\text { Lusardi ve Mitchell } \\
\qquad(2009)\end{array}$ & Hanehalk1 & $\begin{array}{l}\text { Finansal bilgi düzeyi yüksek olan bireylerin } \\
\text { daha fazla emeklilik planı yaptığ } \\
\text { saptanmıştır. }\end{array}$ \\
\hline $\begin{array}{l}\text { Lusardi ve Mitchell } \\
\qquad \text { (2011) }\end{array}$ & Hanehalk1 & $\begin{array}{l}\text { Erkeklerin kadınlara göre daha finansal } \\
\text { okuryazar olduklarını ve finansal bilgi } \\
\text { seviyesi yüksek olan bireylerin emeklilik } \\
\text { için daha iyi plan yaptıkları tespit edilmiştir. }\end{array}$ \\
\hline $\begin{array}{l}\text { Atkinson ve Messy } \\
\text { (2012) }\end{array}$ & Hanehalk1 & $\begin{array}{l}\text { Katılımcıların büyük çoğunluğunun finansal } \\
\text { bilgi düzeylerinin düşük olduğu ve finansal } \\
\text { bilgi ile finansal tutum ve davranış arasında } \\
\text { doğru orantı olduğu saptanmıştır. }\end{array}$ \\
\hline $\begin{array}{l}\text { Allgood ve Walstad } \\
\text { (2013) }\end{array}$ & Hanehalk1 & $\begin{array}{l}\text { Bireylerin finansal okuryazarlık düzeyi } \\
\text { arttıç̧a finansal davranışında olumlu yönde } \\
\text { etkilendiği bulunmuştur. }\end{array}$ \\
\hline
\end{tabular}




\begin{tabular}{|c|c|c|}
\hline $\begin{array}{c}\text { Cameron ve } \\
\text { diğerleri (2013) }\end{array}$ & Üniversite öğrencileri & $\begin{array}{l}\text { Akademik başarı ve gelir düzeyi düşük olan } \\
\text { bireylerin finansal bilgi, tutum ve davranış } \\
\text { düzeylerinin de düşük olduğu saptanmıştır. }\end{array}$ \\
\hline Temizel (2010) & Çalışanlar & $\begin{array}{l}\text { Mavi yakalı çalışanların finansal bilgi } \\
\text { düzeylerinin beyaz yakalı çalışanların } \\
\text { finansal bilgi düzeylerinden yüksek olduğu } \\
\text { bulunmuştur. }\end{array}$ \\
\hline Bayram (2010) & Üniversite öğrencileri & $\begin{array}{l}\text { Öğrencilerin finansal okuryazarlık } \\
\text { seviyelerinin düşük olduğu ancak bunun } \\
\text { farkında olmadıkları bulunmuştur. Ayrıca } \\
\text { ekonomi eğitimi alan öğrencilerin ekonomi } \\
\text { eğitimi almayan öğrencilere göre daha } \\
\text { okuryazar oldukları saptanmıştır. }\end{array}$ \\
\hline Sarıül (2014) & Üniversite öğrencileri & $\begin{array}{l}\text { Öğrencilerin yeterince finansal okuryazar } \\
\text { olmadıkları ve erkek öğrencilerin finansal } \\
\text { okuryazarlık düzeylerinin kadın öğrencilere } \\
\text { göre daha yüksek olduğu bulunmuştur. }\end{array}$ \\
\hline $\begin{array}{l}\text { Ergün, Şahin ve } \\
\text { Ergin (2014) }\end{array}$ & Üniversite öğrencileri & $\begin{array}{l}\text { Öğrencilerin finansal okuryazarlık } \\
\text { seviyelerinin temel seviyede olduğu ve } \\
\text { erkeklerin kadınlara göre daha finansal } \\
\text { okuryazar oldukları bulunmuştur. }\end{array}$ \\
\hline $\begin{array}{c}\text { Şantaş ve Demirgil } \\
\text { (2015) }\end{array}$ & Üniversite öğrencileri & $\begin{array}{l}\text { Son sınıf öğrencilerinin daha çok ekonomi } \\
\text { ve finans gelişmelerini takip ettiği ve } \\
\text { finansal okuryazarlık puan ortalamalarının } \\
\text { cinsiyet, yaş ve sınıf değişkenine göre } \\
\text { farklılık gösterdiği sonucu bulunmuştur. }\end{array}$ \\
\hline $\begin{array}{l}\text { Kılıç ve diğerleri } \\
\qquad(2015)\end{array}$ & Üniversite öğrencileri & $\begin{array}{l}\text { Öğrencilerin finansal } \\
\text { düzeylerinin temel sevuryazarlık } \\
\text { erkeklerin kadınlara göre daha finansal } \\
\text { okuryazar oldukları ve katılımcıların } \\
\text { finansal okuryazarlıkla ilgili yeterli düzeyde } \\
\text { bilgiye sahip olmadıkları, konunun yatırım } \\
\text { olduğu, en çok hakim oldukları konunun ise } \\
\text { bireysel bankacılık olduğu bulunmuştur. }\end{array}$ \\
\hline $\begin{array}{l}\text { Er, Şahin ve Mutlu } \\
\text { (2017) }\end{array}$ & Üniversite öğrencileri & $\begin{array}{l}\text { Öğrencilerin yeterince finansal okuryazar } \\
\text { olmadıkları, aynı zamanda finansal bilgi } \\
\text { düzeylerinin de düşük olduğu saptanmıştır. }\end{array}$ \\
\hline $\begin{array}{c}\text { Güler ve Tunahan } \\
\text { (2017) }\end{array}$ & Hanehalk1 & $\begin{array}{l}\text { Hane halkının büyük bir bölümünün finansal } \\
\text { okuryazarlık düzeylerinin düşük olduğu ve } \\
\text { finansal okuryazarlığın tasarruf davranış1 } \\
\text { üzerinde etkili olduğu bulunmuştur. }\end{array}$ \\
\hline $\begin{array}{l}\text { Şahin ve Barış } \\
\text { (2017) }\end{array}$ & Kamu çalışanı & $\begin{array}{l}\text { Finansal gelişmeleri takip etmenin ve ileri } \\
\text { düzeyde finansal okuryazar olmanın tasarruf } \\
\text { davranışını olumlu yönde etkilediği } \\
\text { bulunmuştur. }\end{array}$ \\
\hline
\end{tabular}




\begin{tabular}{|c|c|l|}
\hline $\begin{array}{c}\text { Coşkun ve diğerleri } \\
\text { (2018) }\end{array}$ & Hanehalk1 & $\begin{array}{l}\text { Finansal işlemler sebebiyle finansal } \\
\text { kuruluşlarla anlaşmazlığa düşerek tüketici } \\
\text { hakem heyetlerine veya mahkemelere } \\
\text { başvurma sonucu hak arayanları, finansal } \\
\text { okuryazarlı seviyesinin k1smen fazla } \\
\text { olduğu sonucuna ulaşıllmıştır. }\end{array}$ \\
\hline Boz (2019) & Öğrenci velileri & $\begin{array}{l}\text { Finansal bilgi düzeyinin finansal katılımı } \\
\text { etkilemediği tespit edilmiştir. }\end{array}$ \\
\hline
\end{tabular}

\section{Veri ve Yöntem}

Araștırmanın örneklemini, Nazilli İktisadi ve İdari Bilimler Fakültesi'nin farklı bölümlerde öğrenim gören 257 kadın, 216 erkek olmak üzere toplam 473 birey oluşturmuş̧ur. Araştırmanın örneklemini belirlemede kolayda örnekleme yöntemi kullanılmıştır. Çalışmada veriler anket yöntemi ile toplanmıştır. Ankette daha önce yapılmış üç farklı çalışmada (Ergün, Şahin ve Ergin, 2014; Kahraman, 2015; Sarıül, 2015) kullanılan üç farklı finansal okuryazarlık ölçeği yer almıştır. Toplanan verilerin analizinde frekans analizleri, bağımsız gruplar t testi, Anova analizi, Ki-Kare testi ve likert tipi ölçekler için faktör analizi ile güvenilirlik analizi yapılmıştır. Likert tipi ölçek ifadeleri SPSS programında 1:Kesinlikle Katılmıyorum,..., 5: Kesinlikle Katılıyorum olacak şekilde kodlanmıştır. Faktör ve güvenilirlik analizleri için bazı ifadeler ters kodlanmıştır.

\section{Araştırmanın Hipotezleri}

Literatürde yer alan çalışmaların bulgularından hareketle bu çalışma kapsamında test edilecek hipotezler aşağıdaki gibi olușturulmuștur.

H1: Öğrencilerin finansal okuryazarlık göstergelerinden biri olan harcama faktörü ile demografik bilgileri arasında bir ilişki vardır.

H2: Öğrencilerin finansal okuryazarlık göstergelerinden biri olan tutum faktörü ile demografik bilgileri arasında bir ilişki vardır.

H3: Öğrencilerin finansal okuryazarlık göstergelerinden biri olan algı faktörü ile demografik bilgileri arasında bir ilişki vardır.

H4: Öğrencilerin temel finansal okuryazarlık düzeyleri ile demografik bilgileri arasında bir ilişki vardır.

\section{Veri Analizi ve Bulgular}

Öğrencilerin demografik bilgilerine ilişkin anket sorularının frekans analizi sonuçları Tablo 2'de görüldüğü gibidir. Tabloya göre araştırma 257 kadın ve 216 erkek olmak üzere toplam 473 birey üzerinde yapılmıștır. Araştırmaya katılan bireylerin yaş dağılımları incelendiğginde, ağıllıklı olarak 20-22 olduğu görülmektedir. Araştırmaya katılan bireylerin bölümlere göre dağılımı incelendiğinde; İşletme 135, İktisat 99, Siyasi Bilimler ve Kamu Yönetimi 78, Uluslararası Ticaret ve Finansman 81, Maliye 
bölümünde ise 80 kişi öğrenim görmektedirler. Araştırmaya birinci öğretimden 312 ve ikinci öğretimden 161 birey katılmıştır. Araştırmaya katılan bireylerin sınıf düzeylerine bakıldığında, birinci sınıftan 109, ikinci sınıftan 115, üçüncü sınıftan 122 ve dördüncü sınıftan 127 birey katılmıştır. Katılımcıların baba eğitim düzeylerine bakıldığında 267 kişinin baba eğitim düzeyinin ilköğretim mezunu olduğu tespit edilmiştir. Bununla birlikte baba eğitim düzeyi okur- yazar olmayan 10, lise mezunu 132 ve üniversite mezunu 64 kişi yer almaktadır. Katılımcıların anne eğitim düzeylerine bakıldı̆̆ında, ağırlıklı olarak ilköğretim mezunu (340 kişi), geri kalanlardan 38 kişinin okur- yazar olmadığı, 79 kişinin lise, 16 kişinin ise üniversite mezunu oldukları görülmektedir. Araştırmaya katılan bireylerin kişisel aylık gelir düzeyleri incelendiğinde; 188 kişi 470 TL ve altı, 151 kişi 471- 800 TL arası, 54 kişi 801-1200 TL arası, 80 kişi ise 1201 TL ve üzeri kişisel aylık gelire sahip olduklarını belirtmektedirler. 
Tablo 2: Öğrencilerin Demografik Bilgilerine ilişkin Frekans Analizi

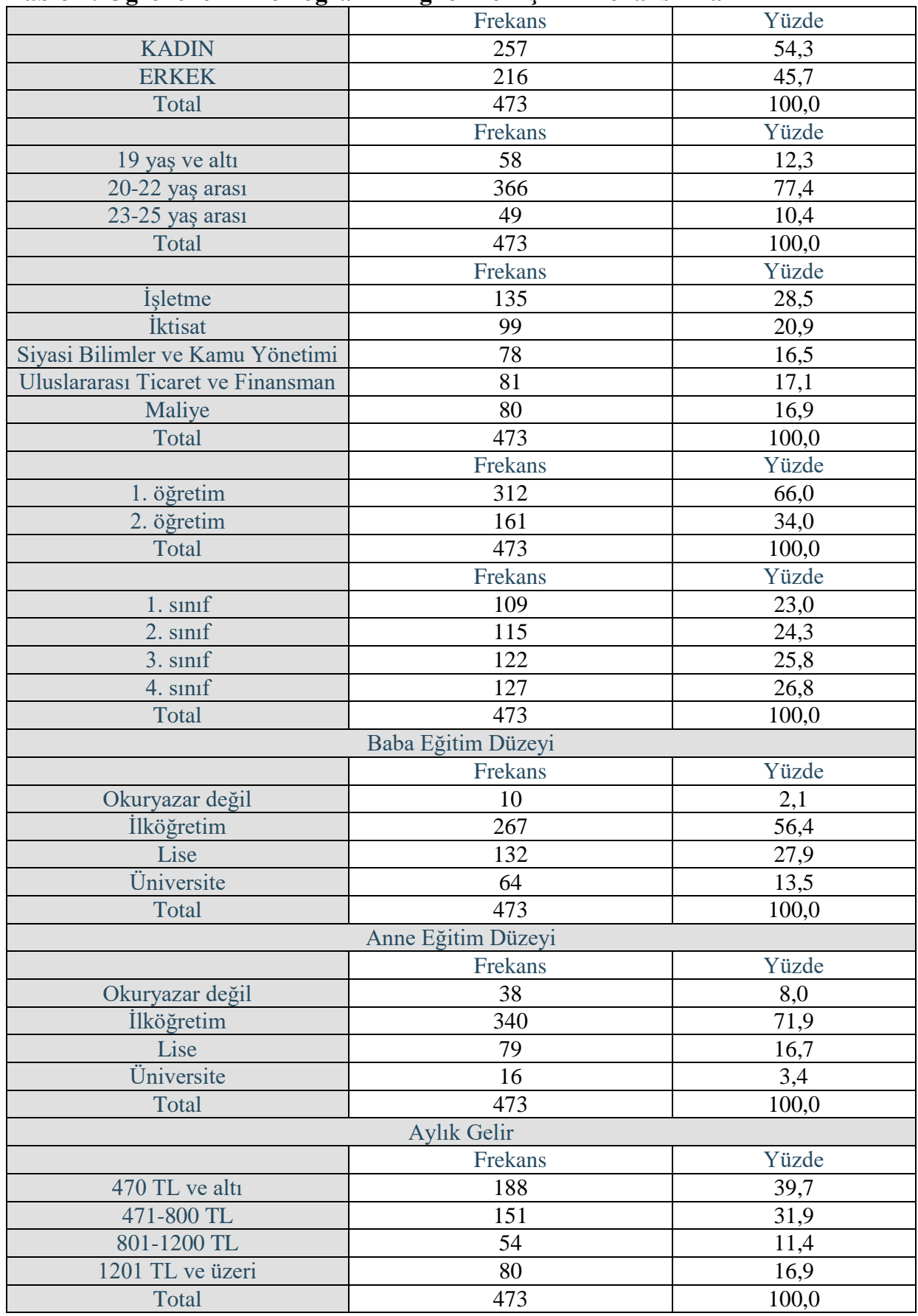


Çalışmada öncelikle Sarıgül (2015) tarafından geliştirilen ölçekten yararlanılarak öğrencilerin finansal okuryazarlık ve alt boyutlarının düzeyleri tespit edilmeye çalışılmıştır. Bu amaçla öncelikle ölçeğe ilişkin faktör analizleri gerçekleştirilmiştir. KMO ve Bartlett testi sonuçlarına göre (Ek 4'te görüldüğü üzere) veri seti faktör analizine uygundur (KMO değeri>0,50). Açıklayıcı faktör analizi sonucunda "Alışveriş yapmak mutluluğum için çok önemlidir" ifadesi ile "Gazetelerin ve televizyonların ekonomi ve finans haberlerini izlerim" ifadesi anti-image korelasyon matrisi ve faktör yükleri dikkate alınarak analizlerden çıkartılmıştır. Faktör analizi daha sonra tekrar gerçekleştirilmiş ve faktörler Ek 1'de görüldüğü gibi oluşmuştur. Analiz sonucunda birden fazla faktörün altında yer alan ve faktör yük değeri 0,50'nin altında olan 3 ifade çıkarılmıştır. Son durumda ölçek 9 madde ve 3 faktörlü son haline (Ek 2) bürünmüştür. Son durumda açıklanan toplam varyans \% 63,156'dır (Ek 3).

Öğrencilerin finansal okuryazarlık anketi ve alt ölçek puanları Tablo 3'te görüldüğü gibi oluşmuştur. Finansal okuryazarlık ölçeği tam puanı toplam 9 maddeye verilen 5:Kesinlikle katılıyorum puanı dikkate alındığında 45 olması gerekmektedir. Aşağıdaki tabloda bu sayının ortalama 31,85 olduğu görülmektedir. Harcama davranışları ölçek tam puanı toplam $20(4 * 5)$ olması gerekmektedir. Öğrencilerin ortalama harcama puanları 6,32 olarak gerçekleşmiştir. Tutum puanlarına bakıldığında 20 üzerinden 15,45, algı puanları 15 üzerinden 10,08 olarak gerçekleşmiştir. Bu doğrultuda genel olarak öğrencilerin finansal okuryazarlık düzeylerinin ortalama puanların üzerinde olduğu söylenebilir. Çarpıklık ve basıklık değerlerinden hareketle ilgili değişkenlerin değerlerinin katılımcılar arasında normal dağıldığını söyleyebiliriz.

Tablo 3: Finansal okuryazarlık ölçeği ve alt ölçek puanları ve tanımlayıcı istatistikler

\begin{tabular}{|c|c|c|c|c|c|c|}
\hline & Minimum & Maksimum & Ortalama & Std. Sapma & Çarpıklık & Basıklık \\
\hline $\begin{array}{c}\text { Finansal Okuryazarlık } \\
\text { Puan1 }\end{array}$ & 12 & 43 & 31,85 & 5,616 &,- 896 &, 703 \\
\hline $\begin{array}{c}\text { Harcama Puan1 (2 } \\
\text { madde) }\end{array}$ & 2 & 10 & 6,32 & 1,437 &, 159 &, 759 \\
\hline Tutum Puan1 (4 madde) & 4 & 20 & 15,45 & 4,030 & $-1,093$ &, 568 \\
\hline Alg1 Puan1 (3 madde) & 3 & 15 & 10,08 & 2,225 &,- 249 &, 172 \\
\hline
\end{tabular}

Aşağıda finansal okuryazarlık ölçeğine ilişkin frekans analizi sonuçları görülmektedir. Buna göre katılımcıların büyük bir kısmı parasal konuları karmaşık olarak algılamaktadır. Katılımcılar ortaya çıkabilecek planlanmamış harcamalar için önceden birikim yapmaktadırlar. Katılımcıların büyük kısmı finansal planlamanın daha çok parasal anlamda zengin kesimler tarafından yapılması gerektiğini düşünmektedirler. Katılımcıların büyük bir kısmı kısa vadeli planlamanın gereksiz olduğunu düşünmektedirler. Katılımcılar genel olarak maddi durumlarının bir şekilde düzeleceğine inanmaktadırlar. Katılımcılar genel olarak finans eğitimi almak istemektedirler. Katılımcıların büyük kısmı alışveriş yapmanın kendilerini mutlu ettiğini belirtmektedirler. Paranın birikimden çok harcanmak için olduğunu belirten ifadeye katılım dereceleri hemen hemen birbirine yakındır. Harcamalarımı kontrol etmekte zorlanırım ifadesine katılım dereceleri birbirine yakın gerçekleşmiştir. Haftalık ve aylık planlama yaptığını ifade eden katılımcıların sayısı diğerlerinden daha yüksek 
gerçekleşmiştir. Katılımcılar "paramın nasıl bittiğini anlamam" ifadesine genel olarak katıldıklarını belirtmektedirler. Katılımcılar genel olarak alışveriş yaparlarken aynı ürünün farklı fiyatlarını kıyasladıklarını belirtmektedirler. Katılımcılar genel olarak satın alma süreçlerinde maddi durumlarını dikkate aldıklarını belirtmektedirler. Yine katılımcıların büyük çoğunluğu ekonomi ve finans haberlerini takip ettiklerini belirtmektedirler.

Tablo 4 : Finansal Okuryazarlık Ölçeği Frekans Analizi

\begin{tabular}{cc}
\hline \multicolumn{2}{c}{ Para ile ilgili konular karmaşıktır. } \\
\hline Frekans & Yüzde \\
52 & 11,0 \\
36 & 7,6 \\
87 & 18,4 \\
164 & 34,7 \\
134 & 28,3 \\
473 & 100,0 \\
\hline Planlanmamış harcamalar için kenarda her zaman para bulundurulmalıdır. \\
\hline Frekans & Yüzde \\
47 & 9,9 \\
22 & 4,7 \\
33 & 7,0 \\
106 & 22,4 \\
265 & 56,0 \\
473 & 100,0 \\
\hline Finansal planlama ve bütçe çok parası olanlar için gereklidir. \\
\hline Frekans & Yüzde \\
100 & 21,1 \\
64 & 13,5 \\
138 & 29,2 \\
95 & 20,1 \\
76 & 16,1 \\
473 & 100,0 \\
\hline Fünlük ve haftalı gibi kısa dönemler için harcama planı yapmak gereksizdir (t) \\
\hline 49 & Yüzde \\
64 & 10,4 \\
105 & 13,5 \\
95 & 22,2 \\
160 & 20,1 \\
473 & 33,8 \\
& 100,0 \\
\hline & \\
\hline &
\end{tabular}




\begin{tabular}{cc}
\hline Ne yaparsam yapayım parasal durumum da bir değişiklik olmaz $(\mathrm{t})$ \\
\hline Frekans & Yüzde \\
57 & 12,1 \\
48 & 10,1 \\
107 & 22,6 \\
84 & 17,8 \\
177 & 37,4 \\
473 & 100,0 \\
\hline Finans konularında eğitim almak isterim. \\
\hline Frekans & Yüzde \\
49 & 10,4 \\
39 & 8,2 \\
117 & 24,7 \\
114 & 24,1 \\
154 & 32,6 \\
473 & 100,0 \\
\hline Alşsveriş yapmak mutluluğum için çok önemlidir. \\
Frekans & Yüzde \\
64 & 13,5 \\
64 & 13,5 \\
112 & 23,7 \\
100 & 21,1 \\
133 & 28,1 \\
473 & 100,0 \\
\hline Para harcanmak içindir, biriktirmek için değil. \\
\hline Frekans & Yüzde \\
111 & 23,5 \\
90 & 19,0 \\
110 & 23,3 \\
76 & 16,1 \\
86 & 18,2 \\
473 & 100,0 \\
\hline Harcamalarımı kontrol etmekte zorlanırım (t) \\
\hline Frekans & Yüzde \\
78 & 16,5 \\
89 & 18,8 \\
115 & 24,3 \\
98 & 20,7 \\
93 & 19,7 \\
473 & 100,0 \\
\hline & \\
\hline & \\
\hline & \\
\hline & \\
\hline &
\end{tabular}




\begin{tabular}{cc}
\hline Haftalık ve aylık harcama planları yaparım. \\
\hline Frekans & Yüzde \\
60 & 12,7 \\
93 & 19,7 \\
114 & 24,1 \\
107 & 22,6 \\
99 & 20,9 \\
473 & 100,0 \\
\hline \multicolumn{1}{c}{ Paramın nasıl bittiğini anlamam (t) } \\
\hline Frekans & Yüzde \\
130 & 27,5 \\
88 & 18,6 \\
103 & 21,8 \\
67 & 14,2 \\
85 & 18,0 \\
473 & 100,0 \\
\hline Alışveriş yaparken aynı ürünün farklı fiyatlarını kıyaslarım. \\
Frekans & Yüzde \\
53 & 11,2 \\
35 & 7,4 \\
57 & 12,1 \\
122 & 25,8 \\
206 & 43,6 \\
473 & 100,0 \\
\hline Bir şey satın alırken maddi durumumu dikkate alııı. \\
Frekans & Yüzde \\
43 & 9,1 \\
43 & 9,1 \\
52 & 11,0 \\
106 & 22,4 \\
229 & 48,4 \\
473 & 100,0 \\
\hline Frekans & Yüzde \\
68 & 14,4 \\
56 & 11,8 \\
133 & 28,1 \\
116 & 24,5 \\
100 & 21,1 \\
473 & 100,0 \\
\hline & \\
Gazetelerin ve televizyonların ekonomi ve finans haberleini zlerim \\
\hline
\end{tabular}

Yapılan bağımsız gruplar $t$ testi ve ANOVA analizleri ile öğrencilerin demografik ve okudukları bölüm ile ilgili özelliklerinin finansal okuryazarlık ve alt olguları ile ilişkisine bakılmıştır. Tablo 5 'te bağımsız gruplar $t$ testi çıktılarından biri olan grup istatistikleri tablosu görülmektedir. Tabloya göre kadın öğrenciler hem genel ölçek 
puanı açısından gerek alt ölçek puanları açısından erkek öğrencilerin üzerinde ortalama puana sahiptirler. $t$ testi sonuçlarına göre $\% 10$ anlamlılık düzeyinde söz konusu farklılık sadece tutum puanları açısından anlamlıdır.

Tablo 5: Cinsiyet*Finansal okuryazarlık ve alt ölçek t testi sonuçları

\begin{tabular}{|c|c|c|c|c|c|}
\hline $\begin{array}{c}\text { Cinsiyet Bağımsız Gruplar t } \\
\text { Testi }\end{array}$ & Cinsiyet & $N$ & $\chi$ & $t$ & $p$ \\
\hline \multirow{2}{*}{ Finansal Okuryazarlık Puanı } & KADIN & 257 & 31,62 & \multirow[b]{2}{*}{602} & \multirow[b]{2}{*}{,547 } \\
\hline & ERKEK & 216 & 31,25 & & \\
\hline \multirow{2}{*}{ Harcama Puanı } & KADIN & 257 & 6,37 & \multirow{2}{*}{1,642} & \multirow{2}{*}{, 101} \\
\hline & ERKEK & 216 & 6,26 & & \\
\hline \multirow{2}{*}{ Tutum Puanı } & KADIN & 257 & 15,76 & \multirow{2}{*}{1,808} & \multirow{2}{*}{, 071} \\
\hline & ERKEK & 216 & 15,09 & & \\
\hline \multirow{2}{*}{ Alg1 Puanı } & KADIN & 257 & 10,13 & \multirow{2}{*}{,490 } & \multirow{2}{*}{,625 } \\
\hline & ERKEK & 216 & 10,03 & & \\
\hline
\end{tabular}

Daha sonra yaş finansal okuryazarlık ilişkisine bakılmış ancak gruplar arasında bir farklılık tespit edilememiştir (Tablo 6).

Tablo 6: Yaş*Finansal okuryazarlık ve alt ölçekler ANOVA testi sonuçları

\begin{tabular}{|c|c|c|c|c|c|}
\hline Yaş ANOVA Testi & Yaş Grubu & $N$ & $\chi$ & $\boldsymbol{F}$ & $p$ \\
\hline \multirow{4}{*}{$\begin{array}{c}\text { Finansal Okuryazarlık } \\
\text { Puanı }\end{array}$} & 19 yaş ve altı & 58 & 31,95 & \multirow{4}{*}{,410 } & \multirow{4}{*}{,664 } \\
\hline & 20-22 yaş aras1 & 366 & 31,93 & & \\
\hline & $23-25$ yaş arası & 49 & 31,16 & & \\
\hline & Total & 473 & 31,85 & & \\
\hline \multirow{4}{*}{ Harcama Puanı } & 19 yaş ve altı & 58 & 6,43 & \multirow{4}{*}{1,048} & \multirow{4}{*}{, 352} \\
\hline & $20-22$ yaş arası & 366 & 6,27 & & \\
\hline & $23-25$ yaş arası & 49 & 6,55 & & \\
\hline & Total & 473 & 6,32 & & \\
\hline \multirow{4}{*}{ Tutum Puanı } & 19 yaş ve altı & 58 & 15,33 & \multirow{4}{*}{,316 } & \multirow{4}{*}{, 729} \\
\hline & $20-22$ yaş arası & 366 & 15,52 & & \\
\hline & $23-25$ yaş arası & 49 & 15,06 & & \\
\hline & Total & 473 & 15,45 & & \\
\hline \multirow{4}{*}{ Alg1 Puanı } & 19 yaş ve altı & 58 & 10,19 & \multirow{4}{*}{1,578} & \multirow{4}{*}{,208 } \\
\hline & $20-22$ yaş aras1 & 366 & 10,14 & & \\
\hline & 23-25 yaș arası & 49 & 9,55 & & \\
\hline & Total & 473 & 10,08 & & \\
\hline
\end{tabular}

Çalışmanın devamında öğrencilerin okudukları bölüm ve finansal okuryazarlık seviyeleri ve alt ölçek puanları arasındaki ilişkilere bakılmış ancak sadece algı boyutunda bir farklılık tespit edilmiştir. Yapılan Tukey analizi sonucunda bu farklılığın Siyasi bilimler ve Maliye öğrencileri ortalamaları arasında olduğu ve Maliye öğrencilerinin ortalama puanlarının diğer bölüm öğrencilerin daha yüksek olduğu görülmüştür. 
Tablo 7: Bölüm*Finansal okuryazarlık ve alt ölçekler ANOVA testi sonuçları

\begin{tabular}{|c|c|c|c|c|c|}
\hline \multicolumn{2}{|c|}{ Bölüm ANOVA Testi } & $N$ & $\chi$ & $F$ & $p$ \\
\hline \multirow{6}{*}{$\begin{array}{c}\text { Finansal Okuryazarlık } \\
\text { Puanı }\end{array}$} & İşletme & 135 & 31,39 & \multirow{6}{*}{, 562} & \multirow{6}{*}{,691 } \\
\hline & İktisat & 99 & 32,33 & & \\
\hline & $\begin{array}{c}\text { Siyasi Bilimler ve Kamu } \\
\text { Yönetimi }\end{array}$ & 78 & 31,86 & & \\
\hline & $\begin{array}{c}\text { Uluslararası Ticaret ve } \\
\text { Finansman }\end{array}$ & 81 & 31,62 & & \\
\hline & Maliye & 80 & 32,28 & & \\
\hline & Total & 473 & 31,85 & & \\
\hline \multirow{6}{*}{ Harcama Puanı } & İşletme & 135 & 6,46 & \multirow{6}{*}{, 874} & \multirow{6}{*}{,479 } \\
\hline & İktisat & 99 & 6,23 & & \\
\hline & $\begin{array}{c}\text { Siyasi Bilimler ve Kamu } \\
\text { Yönetimi }\end{array}$ & 78 & 6,19 & & \\
\hline & $\begin{array}{c}\text { Uluslararası Ticaret ve } \\
\text { Finansman }\end{array}$ & 81 & 6,19 & & \\
\hline & Maliye & 80 & 6,44 & & \\
\hline & Total & 473 & 6,32 & & \\
\hline \multirow{6}{*}{ Tutum Puanı } & İşletme & 135 & 14,84 & \multirow{6}{*}{1,614} & \multirow{6}{*}{, 170} \\
\hline & İktisat & 99 & 16,07 & & \\
\hline & $\begin{array}{c}\text { Siyasi Bilimler ve Kamu } \\
\text { Yönetimi }\end{array}$ & 78 & 15,67 & & \\
\hline & $\begin{array}{c}\text { Uluslararas1 Ticaret ve } \\
\text { Finansman }\end{array}$ & 81 & 15,20 & & \\
\hline & Maliye & 80 & 15,76 & & \\
\hline & Total & 473 & 15,45 & & \\
\hline \multirow{6}{*}{ Alg1 Puanı } & İșletme & 135 & 10,21 & \multirow{6}{*}{2,383} & \multirow{6}{*}{, 051} \\
\hline & İktisat & 99 & 10,07 & & \\
\hline & $\begin{array}{c}\text { Siyasi Bilimler ve Kamu } \\
\text { Yönetimi }\end{array}$ & 78 & 9,62 & & \\
\hline & $\begin{array}{c}\text { Uluslararası Ticaret ve } \\
\text { Finansman }\end{array}$ & 81 & 9,84 & & \\
\hline & Maliye & 80 & 11,00 & & \\
\hline & Total & 473 & 10,15 & & \\
\hline
\end{tabular}

Öğrencilerin ebeveynlerinin eğitim düzeyleri ile finansal okuryazarlık düzeyleri ve alt ölçek puanları arasındaki ilişkilere bakıldığında ise yine aynı şekilde herhangi bir ilişkiden söz edilememektedir (Tablo 7). Bununla birlikte baba eğitim düzeyi açısından bakıldığında \%10 anlamlılık seviyesinde "Algı" puanının farklılaștığı görülmektedir. Bu farklılığın hangi gruplardan kaynaklandığının tespiti için Post Hoc testlerinden biri olan Tukey testi yapılmıştır. Test sonucunda okuryazar olmayan grup ile lise eğitimi almış grup arasında bir farklılık olduğu ve baba eğitim düzeyi lise olan grubun algı puanının daha yüksek olduğu tespit edilmiştir (Ek 5). 
Tablo 8: Aile Eğitim Düzeyi*Finansal okuryazarlık ve alt ölçekler t testi sonuçları

\begin{tabular}{|c|c|c|c|c|c|c|c|c|c|}
\hline \multirow{2}{*}{\multicolumn{2}{|c|}{$\begin{array}{c}\text { Aile Eğitim Düzeyi ANOVA } \\
\text { Testi }\end{array}$}} & \multicolumn{4}{|c|}{ Baba } & \multicolumn{4}{|c|}{ Anne } \\
\hline & & $N$ & $\chi$ & $F$ & $p$ & $N$ & $\chi$ & $F$ & $p$ \\
\hline \multirow{5}{*}{$\begin{array}{c}\text { Finansal } \\
\text { Okuryazarlık Puanı }\end{array}$} & $\begin{array}{c}\text { Okuryazar } \\
\text { değil }\end{array}$ & 10 & 28,80 & \multirow{5}{*}{1,658} & \multirow{5}{*}{, 175} & 38 & 30,92 & \multirow{5}{*}{1,056} & \multirow{5}{*}{, 368} \\
\hline & İlköğretim & 267 & 31,98 & & & 340 & 32,14 & & \\
\hline & Lise & \multirow{3}{*}{\multicolumn{2}{|c|}{\begin{tabular}{|l|l|}
32 & 32,21 \\
54 & 31,05 \\
73 & 31,85 \\
\end{tabular}}} & & & 79 & 31,18 & & \\
\hline & Üniversite & & & & & 16 & 31,38 & & \\
\hline & Total & & & & & 473 & 31,85 & & \\
\hline \multirow{5}{*}{ Harcama Puanı } & $\begin{array}{c}\text { Okuryazar } \\
\text { değil }\end{array}$ & 10 & 6,00 & \multirow{5}{*}{,531 } & \multirow{5}{*}{,661 } & \begin{tabular}{|l|}
38 \\
\end{tabular} & 6,21 & \multirow{5}{*}{, 198} & \multirow{5}{*}{, 898} \\
\hline & İlköğretim & 267 & 6,37 & & & 340 & 6,34 & & \\
\hline & Lise & 132 & 6,30 & & & 79 & 6,30 & & \\
\hline & Üniversite & 64 & 6,17 & & & 16 & 6,13 & & \\
\hline & Total & 473 & 6,32 & & & 473 & 6,32 & & \\
\hline \multirow{5}{*}{ Tutum Puanı } & $\begin{array}{c}\text { Okuryazar } \\
\text { değil }\end{array}$ & 10 & 14,20 & \multirow{5}{*}{1,214} & \multirow{5}{*}{,304 } & \begin{tabular}{|l|}
38 \\
340 \\
\end{tabular} & \begin{tabular}{|c|}
14,95 \\
1571 \\
\end{tabular} & \multirow{5}{*}{1,679} & \multirow{5}{*}{, 171} \\
\hline & İlköğretim & 267 & 15,61 & & & \begin{tabular}{|l|}
740 \\
70 \\
\end{tabular} & $\mid$\begin{tabular}{|l|}
$15, / 1$ \\
1470
\end{tabular} & & \\
\hline & Lise & 132 & 15,58 & & & \begin{tabular}{|l|}
19 \\
19
\end{tabular} & $14, / 0 \mid$ & & \\
\hline & Üniversite & 64 & 14,72 & & & 16 & 14,94 & & \\
\hline & Total & 473 & 15,45 & & & 473 & 15,45 & & \\
\hline \multirow{6}{*}{ Alg1 Puanı } & Okuryazar & 10 & 860 & \multirow{6}{*}{2,214} & \multirow{6}{*}{$4,086^{* * *}$} & 38 & 9,76 & \multirow{6}{*}{364} & \multirow{6}{*}{,779 } \\
\hline & değil & 10 & 0,00 & & & 340 & 10,09 & & \\
\hline & İlköğretim & 267 & 10,00 & & & 79 & 10,18 & & \\
\hline & Lise & 132 & 10,33 & & & \begin{tabular}{|l|}
16 \\
\end{tabular} & 10,31 & & \\
\hline & Üniversite & 64 & 10,16 & & & \begin{tabular}{|l|}
10 \\
473 \\
\end{tabular} & & & \\
\hline & Total & 473 & 10,08 & & & & 10,08 & & \\
\hline
\end{tabular}

Çalışmada daha sonra Kahraman (2015) tarafından yapılan çalışmada kullanılan ölçek ile elde edilen verilerin analizine geçilmiştir. Tablo 9' da tanımlayıcı istatistikler görülmektedir. Buna göre öğrenciler tarafından en fazla bilinen kavramlar sırasıyla riskgetiri oranları, hazine bonosu ve ek limit ve faiz oranlarıdır. En az bilinenler ise sırasıyla kredi kartı ödeme tarihi, kredi kartı faiz oranları ve kredi kartı minimum ödeme tutarlarıdır. Çarpıklık-basıklık değerlerinden değişkenlerin normal dağılım sergiledikleri görülmektedir. 
Tablo 9: Bazı Temel Finansal Kavramlar ile ilgili Tanımlayıcı İstatistikler

\begin{tabular}{|c|c|c|c|c|}
\hline & $X$ & $s$ & Çarpıklık & Basıklık \\
\hline Bileşik Faiz & 2,2156 &, 70110 &,- 326 &,- 943 \\
\hline Basit Faiz & 1,9852 &, 72031 &, 022 & $-1,067$ \\
\hline Kredi kartı ödeme tarihi & 1,5307 &, 69777 &, 942 &,- 396 \\
\hline Kredi Kartı faiz oranları & 1,7844 &, 76469 &, 387 & $-1,199$ \\
\hline $\begin{array}{c}\text { Kredi Kartı Minimum Ödeme } \\
\text { Tutarı }\end{array}$ & 1,7886 &, 80893 &, 403 & $-1,360$ \\
\hline Hazine bonosu & 2,3890 &, 68954 &,- 686 &,- 685 \\
\hline Hisse Senedi & 2,0317 &, 73433 &,- 050 & $-1,140$ \\
\hline Risk getiri oranları & 2,4313 &, 67963 &,- 786 &,- 540 \\
\hline Bireysel Emeklilik Sigortas1 & 2,0275 &, 77109 &,- 047 & $-1,315$ \\
\hline Hayat sigortası & 1,9810 &, 78226 &, 033 & $-1,363$ \\
\hline Ek limit ve faiz oranları & 2,3467 &, 72067 &,- 629 &,- 856 \\
\hline
\end{tabular}

Tablo 10'da ise temel finansal kavramların bilinirliği ile öğrencilerin cinsiyetlerinin ilişkili olup olmadıklarının tespiti için gerçekleştirilmiş bağımsız gruplar t testi sonuçları görülmektedir. Tabloda yer alan sonuçlara göre bileşik faiz, basit faiz, kredi kartı ödeme tarihi, kredi kartı faiz oranları, minimum ödeme tutarı kavramlarının bilinirlik düzeyleri ile katılımcıların cinsiyetleri arasında istatistiksel açıdan anlamlı bir ilişki söz konusudur. Buna göre kadın bireylerin bu kavramlarla ilgili bilgi düzeyleri erkek öğrencilerden anlamlı derecede yüksektir. 
Tablo 10: Bazı Temel Finansal Kavramların Bilinilirliği ile Cinsiyet İlișkisi $t$ testi

\begin{tabular}{|c|c|c|c|c|c|c|}
\hline & Cinsiyet & $N$ & $X$ & $S$ & $t$ & $p$ \\
\hline \multirow{2}{*}{ Bileşik Faiz } & Kadın & 257 & 2,2879 & ,65160 & \multirow{2}{*}{2,459} & \multirow{2}{*}{, $014^{* * *}$} \\
\hline & Erkek & 216 & 2,1296 & ,74824 & & \\
\hline \multirow{2}{*}{ Basit Faiz } & Kadın & 257 & 2,0700 & ,69242 & \multirow{2}{*}{2,815} & \multirow{2}{*}{, $005^{*}$} \\
\hline & Erkek & 216 & 1,8843 & ,74117 & & \\
\hline \multirow{2}{*}{$\begin{array}{l}\text { Kredi kartı ödeme } \\
\text { tarihi }\end{array}$} & Kadın & 257 & 1,6109 & ,75283 & \multirow{2}{*}{2,747} & \multirow{2}{*}{, $006^{*}$} \\
\hline & Erkek & 216 & 1,4352 & ,61415 & & \\
\hline \multirow{2}{*}{$\begin{array}{c}\text { Kredi Kart1 faiz } \\
\text { oranları }\end{array}$} & Kadın & 257 & 1,9066 & ,78002 & \multirow{2}{*}{3,848} & \multirow{2}{*}{, $000^{*}$} \\
\hline & Erkek & 216 & 1,6389 & ,72122 & & \\
\hline \multirow{2}{*}{$\begin{array}{l}\text { Kredi Kart1 Minimum } \\
\text { Ödeme Tutar1 }\end{array}$} & Kadın & 257 & 1,9027 & ,82578 & \multirow{2}{*}{3,384} & \multirow{2}{*}{, $001^{*}$} \\
\hline & Erkek & 216 & 1,6528 & ,76844 & & \\
\hline \multirow{2}{*}{ Hazine bonosu } & Kadın & 257 & 2,3696 & ,70124 & \multirow{2}{*}{,- 666} & \multirow{2}{*}{, 506} \\
\hline & Erkek & 216 & 2,4120 & ,67627 & & \\
\hline \multirow{2}{*}{ Hisse Senedi } & Kadın & 257 & 2,0700 & ,71463 & \multirow{2}{*}{1,239} & \multirow{2}{*}{,216 } \\
\hline & Erkek & 216 & 1,9861 & ,75624 & & \\
\hline \multirow{2}{*}{ Risk getiri oranları } & Kadın & 257 & 2,4397 & ,69965 & \multirow{2}{*}{,293 } & \multirow{2}{*}{,770 } \\
\hline & Erkek & 216 & 2,4213 & ,65650 & & \\
\hline \multirow{2}{*}{$\begin{array}{c}\text { Bireysel Emeklilik } \\
\text { Sigortas1 }\end{array}$} & Kadın & 257 & 2,0623 & ,77813 & \multirow{2}{*}{1,070} & \multirow{2}{*}{,285 } \\
\hline & Erkek & 216 & 1,9861 & ,76237 & & \\
\hline \multirow{2}{*}{ Hayat sigortas1 } & Kadın & 257 & 2,0311 & ,77498 & \multirow{2}{*}{1,523} & \multirow{2}{*}{,128 } \\
\hline & Erkek & 216 & 1,9213 & ,78847 & & \\
\hline \multirow{2}{*}{$\begin{array}{c}\text { Ek limit ve Faiz } \\
\text { oranları }\end{array}$} & Kadın & 257 & 2,3813 & ,73056 & \multirow{2}{*}{1,139} & \multirow{2}{*}{,255 } \\
\hline & Erkek & 216 & 2,3056 & ,70820 & & \\
\hline $\begin{array}{l}* \% 1, * * \% 5, * * \% 1 \\
\text { SPSS kodlamasl: } 1: Y \\
\text { biliyorum }\end{array}$ & inlamlılt & & i ifade & ktedir. & & \\
\hline
\end{tabular}

Tablo 11'e bakıldığında öğrencilerin bölümleri ile finansal kavram bilinirliği ANOVA testi sonuçları görülmektedir. Analiz sonucunda bölüm ile finansal kavram bilgisi arasında ilişki olduğu ortaya çıkmıştır. Buna göre finansal kavramların bilinirliği ve öğrencilerin bölümleri arasında istatistiksel olarak anlamlı bir ilişki söz konusudur.

Tablo 11: Bazı Temel Finansal Kavramların Bilinilirliği ile Bölüm İlişkisi ANOVA testi

\begin{tabular}{|c|c|c|}
\hline Finansal Kavramlar & $F$ & $p$ \\
\hline Bileşik Faiz & 4,726 &, $001^{*}$ \\
\hline Basit Faiz & 2,961 &, $020^{* *}$ \\
\hline Kredi kartı ödeme tarihi & 3,468 &, $008^{*}$ \\
\hline Kredi Kart faiz oranları & 4,393 &, $002^{*}$ \\
\hline Kredi Kart1 Minimum Ödeme Tutarı & 3,739 &, $005^{*}$ \\
\hline Hazine bonosu & 7,264 &, $000^{*}$ \\
\hline Hisse Senedi & 2,921 &, $018^{* *}$ \\
\hline Risk getiri oranları & 3,024 &, $000^{*}$ \\
\hline Bireysel Emeklilik Sigortası & 14,262 &, $000^{*}$ \\
\hline Hayat sigortası & 5,682 &, $001^{*}$ \\
\hline
\end{tabular}


Yapılan Tukey testleri sonucunda bileşik faiz için farklılı̆̆ı İşletme ve Siyasi Bilimler ve Kamu Yönetimi bölümleri ile Uluslararası Ticaret ve Finansman bölümü arasında anlamlı olduğu ve İşletme ve Siyasi Bilimler ve Kamu Yönetimi öğrencilerinin bileşik faiz bilgisinin daha yüksek olduğu tespit edilmiş̧tir. Basit faiz için farklılı̆̆ın yine İşletme ve Uluslararası Ticaret ve Finansman bölümü arasında anlamlı olduğu görülmüş ve İşletme öğrencilerinin bileşik faiz bilgisinin daha yüksek olduğu tespit edilmiştir. Kredi kartı ödeme tarihi açısından bakıldığında İktisat ve Uluslararası Ticaret ve Finansman bölümü arasındaki farklılığın anlamlı olduğu görülmüştür. Uluslararası Ticaret ve Finansman bölümü öğrencilerinin bilgisi daha yüksektir. Kredi kartı faiz oranları açısından bakıldığında ise en yüksek sayıda farklılık olan grupların burada olduğu görülmektedir. İşletme ve İktisat, İktisat ile Uluslararası Ticaret ve Finansman ve Siyasi Bilimler ve Kamu Yönetimi arasındaki farklılıkların anlamlı olduğu görülmüştür. En yüksek bilinirlik düzeyine sahip grupların sırasıyla İşletme, Siyasi ve Uluslararası Ticaret olduğu görülmektedir. "Kredi Kartı Minimum Ödeme Tutarı" bağlamında ise İktisat, İșletme ve Uluslararası Ticaret arasındaki farklılıkların anlamlı olduğu görülmektedir. En yüksek bilinirlik düzeylerinin sırasıyla Uluslararası Ticaret, Maliye ve İşletmede olduğu en düşük ise İktisat bölümü öğrencilerinde olduğu görülmüştür. Hazine bonusu açısından farklılı̆̆ın İktisat bölümü ve diğer tüm bölümler arasında olduğu görülmüştür. İktisat bölümü öğrencileri arasında hazine bonosunun bilinirliği en düşük seviyededir. En yüksek ise İşletme ve Uluslararası Ticaret ve Finansman öğrencileri arasındadır. Hisse senedi açısından ise İktisat ve Maliye bölümleri arasında anlamlı bir farklılık söz konusudur. Maliye bölümü öğrencilerinin bilgi düzeyi daha yüksektir. Risk-getiri oranları açısından ise yine İşletme ve İktisat bölümü öğrencileri arasında anlamlı bir farklılık söz konusudur. İşletme bölümü öğrencilerinin bilgi düzeyi anlamlı derecede yüksektir. Bireysel emeklilik sigortası açısından ise yine İktisat bölümü öğrencilerinin bilgi düzeyi diğer bölüm öğrencilerinden anlamlı derecede düşüktür. Hayat sigortası açısından Uluslararası Ticaret ve Finansman bölümü öğrencilerinin bilgi düzeyleri diğer bölüm öğrencilerinden anlamlı derecede yüksektir. Ek limit ve faiz oranları açısından ise yine İktisat bölümü öğrencilerinin puan ortalamalarının diğer bölüm öğrencilerinden anlamlı derecede düşük olduğu görülmüsstür.

Sonraki aşamada ise Ergün, Şahin ve Ergin (2014) tarafından yapılan çalışmada kullanılan ölçekle toplanan veriler üzerinden analizler gerçekleştirilmiştir. İlk olarak finansal okuryazarlık sorularına verilen cevapların doğru ve yanlış yüzdelerine bakılmıştır. Tablo 12 'de görüldüğü üzere temel faiz bilgisi sorusuna cevap veren öğrencilerden \%59,2'si doğru cevap vermiş̧ir. Bu öğrencilerin \%55,6's1 kadın \%63,4'ü erkek öğrencilerden oluşmaktadırlar. Bununla birlikte soruya verilen cevaplar arasındaki fark cinsiyet açısından \%10 anlamlılık seviyesinde anlamlıdır. İkinci soru olan enflasyon sorusuna verilen cevaplar incelendiğinde yine erkek öğrencilerin daha yüksek bir doğru cevap yüzdesine sahip oldukları görülmektedir. Yalnız bu fark istatistiksel olarak anlamlı değildir. Borsanın ana işlevi sorusuna yine erkek öğrenciler daha yüksek oranda doğru cevap vermişlerdir. Ancak ortaya çıkan fark anlamlı değildir. Dördüncü soru yatırım fonları bilgisini içermektedir. Bu soruya kadın öğrenciler daha yüksek oranda doğru cevap vermişlerdir. Ancak fark anlamlı değildir. Faiz oranı ve tahvil fiyatları ilişkisini içeren beşinci soruya yine bayan öğrenciler daha yüksek oranda 
doğru cevap vermişlerdir. Bununla birlikte fark anlamlı değildir. Altıncı soru çeşitlendirme stratejisi ile ilgilidir ve erkek öğrenciler daha yüksek oranda doğru cevap vermesine rağmen ortaya çıkan fark anlamlı olmamıştır. Finansal varlık riskini içeren yedinci soruya verilen cevaplara bakıldığında da anlamlı bir fark söz konusu değildir. Sekizinci soruda ise öğrencilere finansal varlıkların volatilitesi ile ilgili bilgi sorusu yöneltilmiş ve erkek öğrenciler daha yüksek oranda doğru cevap vermişlerdir. Ortaya çıkan fark anlamlıdır. 9. soruda ise öğrencilere varlık çeşitlendirmesi ile ilgili bilgi sorusu yöneltilmiş fakat ortaya çıkan fark anlamlı olmamıştır.

Tablo 12: Finansal Okuryazarlık Sorularına Verilen Cevaplar ve Cinsiyet İlişkisi

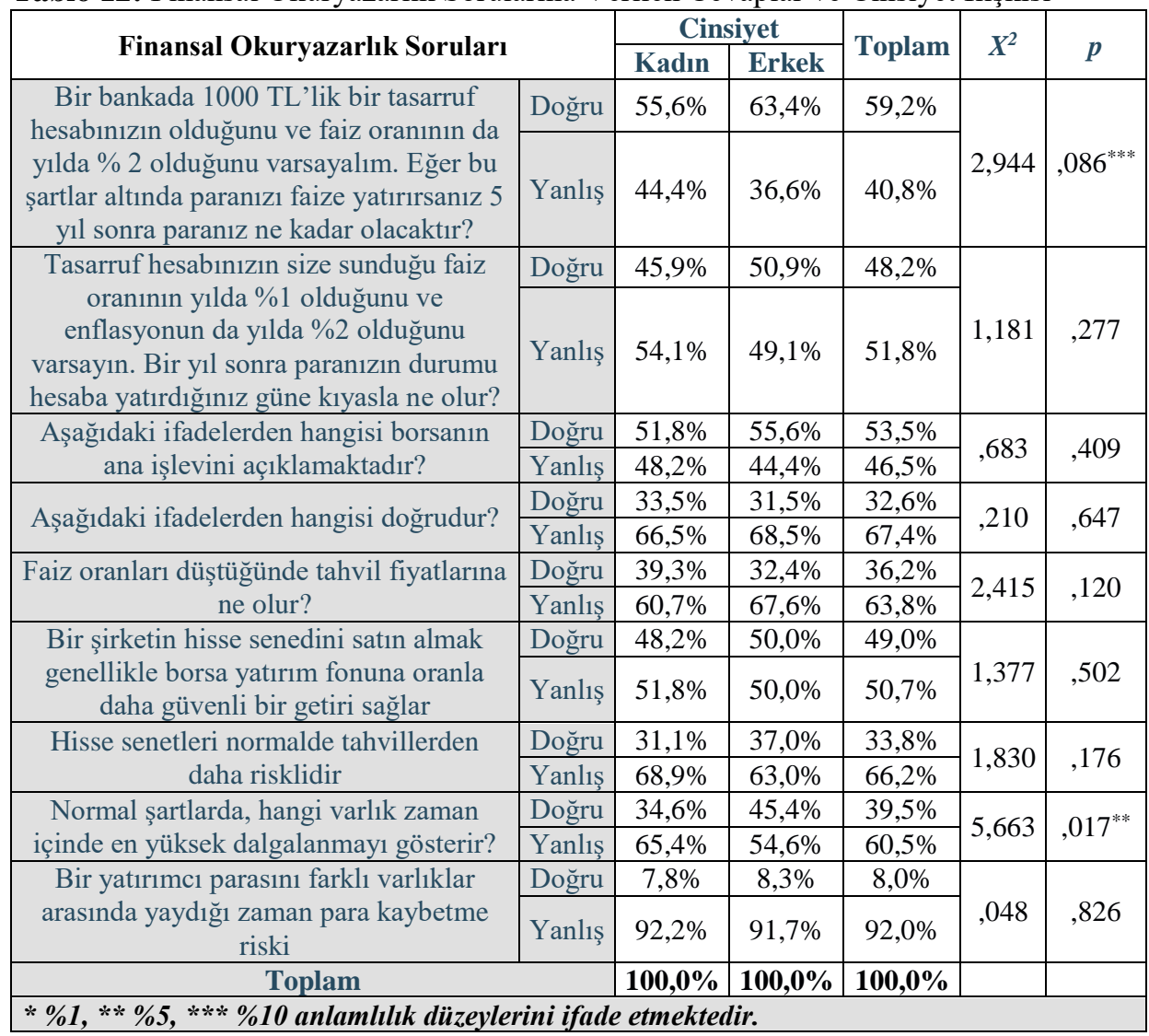

Öğrencilerin temel finansal okuryazarlık sorularına verdikleri cevaplar ile okudukları bölüm arasındaki ilişkilerin tespiti için yine Ki-Kare testine başvurulmuştur. Test sonucunda temel faiz bilgisi sorusuna İşletme ve Maliye bölümü öğrencilerinin en yüksek oranda doğru cevap verdikleri ortaya çıkmıştır. Ancak istatistiksel olarak anlamlı bir sonuçtan söz edilememektedir. İstatistiksel anlamda anlamlı bir farklılığın ortaya çıktığı finansal okuryazarlık soruları, temel enflasyon bilgisi (İktisat bölümünde yüksektir), yatırım fonları bilgisi (İktisat bölümünde yüksektir, Maliyede oldukça 
düşüktür), faiz-tahvil fiyatı ilişkisi (İktisat bölümünde yüksektir), çeşitlendirme stratejisi (İşletme ve Siyasi Bilimlerde yüksektir), finansal varlıkların riski (işletme ve siyasi bilimlerde oldukça düşüktür), finansal varlıkların volatilitesi (Siyasi bilimlerde oldukça düşüktür) ve finansal varlık çeşitlendirme stratejisi (Uluslararası Ticaret ve Finansman bölümünde daha yüksek bir doğru oranı söz konusu) ile ilgili sorulardır.

Tablo 13: Finansal Okuryazarlık Sorularına Verilen Cevaplar ve Bölüm İlişkisi

\begin{tabular}{|c|c|c|c|c|c|c|c|c|c|}
\hline & \multicolumn{5}{|c|}{ Bölüm } & \multirow[b]{2}{*}{ Toplam } & \multirow[b]{2}{*}{$X^{2}$} & \multirow[b]{2}{*}{$p$} \\
\hline & & İşletme & İktisat & \begin{tabular}{|c|} 
Siyasi \\
Bilimler \\
ve Kamu \\
Yönetimi \\
\end{tabular} & \begin{tabular}{|} 
Uluslararası \\
Ticaret ve \\
Finansman
\end{tabular} & Maliye & & & \\
\hline \multirow[b]{2}{*}{\begin{tabular}{|c|} 
Bir bankada \\
1000 TL'lik bir \\
tasarruf \\
hesabınızın \\
olduğunu ve faiz \\
oranının da \\
yılda \% 2 \\
olduğunu \\
varsayalım. \\
Eğer bu şartlar \\
altında paranızı \\
faize yatırırsanız \\
5 yıl sonra \\
paranız ne kadar \\
olacaktır?
\end{tabular}} & Doğru & $63,0 \%$ & $61,6 \%$ & $46,2 \%$ & $59,3 \%$ & $62,5 \%$ & $59,2 \%$ & & \\
\hline & Yanlış & $37,0 \%$ & $38,4 \%$ & $53,8 \%$ & $40,7 \%$ & $37,5 \%$ & $40,8 \%$ & 6,888 & ,142 \\
\hline \multirow[b]{2}{*}{\begin{tabular}{|c} 
Tasarruf \\
hesabınızın size \\
sunduğu faiz \\
oranının yılda \\
$\% 1$ olduğunu ve \\
enflasyonun da \\
y1lda $\% 2$ \\
olduğunu \\
varsayın. Bir yıl \\
sonra paranızın \\
durumu hesaba \\
yatırdığınız \\
güne kıyasla ne \\
olur?
\end{tabular}} & Doğru & $45,2 \%$ & $65,7 \%$ & $47,4 \%$ & $45,7 \%$ & $35,0 \%$ & $48,2 \%$ & & \\
\hline & Yanlış & $54,8 \%$ & $34,3 \%$ & $52,6 \%$ & $54,3 \%$ & $65,0 \%$ & $51,8 \%$ & 18,382 &, $001^{*}$ \\
\hline \multirow{2}{*}{\begin{tabular}{|c|} 
Aşağıdaki \\
ifadelerden \\
hangisi borsanın \\
ana işlevini \\
açıklamaktadır?
\end{tabular}} & Doğru & $48,1 \%$ & $59,6 \%$ & $52,6 \%$ & $54,3 \%$ & $55,0 \%$ & $53,5 \%$ & & \\
\hline & Yanlış & $51,9 \%$ & $40,4 \%$ & $47,4 \%$ & $45,7 \%$ & $45,0 \%$ & $46,5 \%$ & 3,155 &, 532 \\
\hline
\end{tabular}




\begin{tabular}{|c|c|c|c|c|c|c|c|c|c|}
\hline \multirow{2}{*}{\begin{tabular}{|c|} 
Aşağıdaki \\
ifadelerden \\
hangisi \\
doğrudur? \\
\end{tabular}} & Doğru & $34,1 \%$ & $41,4 \%$ & $32,1 \%$ & $30,9 \%$ & $21,3 \%$ & $32,6 \%$ & \multirow[b]{2}{*}{8,451} & \multirow[b]{2}{*}{$076^{* * * *}$} \\
\hline & Yanlış & $65,9 \%$ & $58,6 \%$ & $67,9 \%$ & $69,1 \%$ & $78,8 \%$ & $67,4 \%$ & & \\
\hline \multirow{2}{*}{$\begin{array}{c}\text { Faiz oranları } \\
\text { düştüğünde } \\
\text { tahvil fiyatlarına } \\
\text { ne olur? } \\
\end{array}$} & Doğru & $28,9 \%$ & $49,5 \%$ & $30,8 \%$ & $37,0 \%$ & $36,3 \%$ & $36,2 \%$ & \multirow[b]{2}{*}{11,728} & \multirow[b]{2}{*}{, $019^{* *}$} \\
\hline & Yanlış & $71,1 \%$ & $50,5 \%$ & $69,2 \%$ & $63,0 \%$ & $63,7 \%$ & $63,8 \%$ & & \\
\hline \multirow[b]{2}{*}{\begin{tabular}{|c|} 
Bir şirketin \\
hisse senedini \\
satın almak \\
genellikle borsa \\
yatırım fonuna \\
oranla daha \\
güvenli bir getiri \\
sağlar \\
\end{tabular}} & Doğru & $51,1 \%$ & $58,6 \%$ & $35,9 \%$ & $40,7 \%$ & $55,0 \%$ & $49,0 \%$ & \multirow[b]{2}{*}{17,195} & \multirow[b]{2}{*}{, $028^{* *}$} \\
\hline & Yanlış & $48,9 \%$ & $41,4 \%$ & $63,1 \%$ & $59,3 \%$ & $45,0 \%$ & $51,0 \%$ & & \\
\hline \multirow{2}{*}{\begin{tabular}{|c|} 
Hisse senetleri \\
normalde \\
tahvillerden \\
daha risklidir \\
\end{tabular}} & Doğru & $24,4 \%$ & $43,4 \%$ & $21,8 \%$ & $40,7 \%$ & $42,5 \%$ & $33,8 \%$ & \multirow[b]{2}{*}{18,854} & \multirow[b]{2}{*}{, $001^{* *}$} \\
\hline & Yanlış & $75,6 \%$ & $56,6 \%$ & $78,2 \%$ & $59,3 \%$ & $57,5 \%$ & $66,2 \%$ & & \\
\hline \multirow{2}{*}{\begin{tabular}{|c|} 
Normal \\
şartlarda, hangi \\
varlık zaman \\
içinde en yüksek \\
dalgalanmayı \\
gösterir?
\end{tabular}} & Doğru & $43,0 \%$ & $35,4 \%$ & $28,2 \%$ & $49,4 \%$ & $40,0 \%$ & $39,5 \%$ & \multirow[b]{2}{*}{8,870} & \multirow[b]{2}{*}{, $064^{* * * *}$} \\
\hline & Yanlış & $57,0 \%$ & $64,6 \%$ & $71,8 \%$ & $50,6 \%$ & $60,0 \%$ & $60,5 \%$ & & \\
\hline \multirow{2}{*}{\begin{tabular}{|c|} 
Bir yatırımc1 \\
parasını farklı \\
varlıklar \\
arasında yaydı.̆ 1 \\
zaman para \\
kaybetme riski \\
\end{tabular}} & \begin{tabular}{|l|} 
Doğru \\
\end{tabular} & $9,6 \%$ & $3,0 \%$ & $5,1 \%$ & $13,6 \%$ & $8,8 \%$ & $8,0 \%$ & \multirow[b]{2}{*}{8,139} & \multirow[b]{2}{*}{, $087^{* * * *}$} \\
\hline & Yanlış & $90,4 \%$ & $97,0 \%$ & $94,9 \%$ & $86,4 \%$ & $91,3 \%$ & $92,0 \%$ & & \\
\hline Toplam & & $100,0 \%$ & $100,0 \%$ & $100,0 \%$ & $100,0 \%$ & $100,0 \%$ & $100,0 \%$ & & \\
\hline
\end{tabular}

\section{Sonuç ve Değerlendirme}

Finansal okuryazarlık, bireylerin ve kurumların finansal açıdan sıkıntıya düşmemeleri için sahip olmaları gereken belirli bir bilgi finansal düzeyini ifade etmektedir. Reel ve finansal piyasalarda aktif olarak faaliyet gösteren bireyler genellikle yaptıkları işlemler veya alıșverişler ile aynı zamanda risk üstlenmekte ve bu riski bilgileri oranında yönetebilmektedirler. Bireylerin yeterli finansal okuryazarlık seviyesine sahip olmaları üstlendikleri riskin daha iyi yönetilmesini ve finansal davranışlarının uygun şekilde ayarlanmasını sağlamaktadır.

Finansal okuryazarlık, finansal kararların mümkün olabilecek en doğru şekilde alınması ve nihayetinde refah seviyesinin arttırılması için gerekli olan farkındalık, bilgi, beceri, tutum ve davranışın bir kombinasyonudur (Compen vd., 2018:2). Bu tanım ile finansal okuryazarlık seviyesinin yükseltilmesinin tek başına nihai bir hedef olmadığı, finansal 
refahı arttırmanın ve korumanın bir aracı olduğu sonucu çıkmaktadır. Bununla birlikte okuryazarlık kavramının temelde iki boyutu söz konusudur. Bunlar; anlama (yeterli finansal bilgiye sahip olma) ve uygulamadır (bu bilgiyi pratik hayattaki olaylarda uygun şekilde kullanma). Başka bir deyişle, bu tanım, finansal okuryazarlığın finansal konularla ilgili bilgi düzeyinin ifadesinden daha geniş bir anlam taşıdığını vurgulamakla birlikte, finansal tutumu (uzun vadeli tasarruf eğilimi gibi) ve finansal davranışı (hanehalkı bütçesinin hazırlanması gibi) içerdiğini belirtmektedir. $\mathrm{Bu}$, finansal okuryazarlığın derinlemesine öğrenme, anlam verme ve eleştirel düşünmeyi içerdiği ve finansal kavramlarla ilgili nesnel bir bilgi düzeyine sahip olmanın yetersiz olduğu anlamına gelmektedir (Compen vd., 2018:2).

Günümüzün zorlu ekonomik şartları altında tüketiciler sıklıkla karmaşık finansal kararlarla karşı karşıya kalmaktadırlar. Özellikle hayatlarının erken dönemlerinde olan gençlerin yaptıkları finansal hataların maliyeti daha yüksek olabilmektedir. Üniversite öğrencileri eğitimleri için almak zorunda oldukları krediler ve kredi kartı borçları nedeniyle iş sahibi olmak bir yana daha mezun dahi olmadan önemli miktarda borç yüklenebilmektedirler. Bu noktada genç nüfusun finansal karar verme yetisine sahip olup olmadıklarının veya ne derece sahip olduklarının araştırılması önemlidir. Finansal bilgi edinimine katkıda bulunan veya engel olan faktörleri anlamak, politika yapıcıların genç nüfusu hedef alan etkili politikalar hazırlamasına yardımcı olacaktır.

$\mathrm{Bu}$ çalışmada genç nüfusun önemli bir örneğini teşkil eden üniversite öğrencileri üzerine bir finansal okuryazarlık düzeyi araştırması yapılmıştır. Çalışmada daha önce yapılan çalışmalarda kullanılmış üç farklı ölçekle veriler toplanmıştır. Burada amaç öğrencilerin finansal okuryazarlık düzeylerinin mümkün olduğunca ayrıntılı olarak incelenmek istenmesidir. Çalışma sonucunda öğrencilerin finansal okuryazarlık düzeylerinin özellikle bölümleri ile yakından ilişkili olduğu görülmüştür. Bununla birlikte cinsiyet, yaş ve anne-baba eğitim düzeyleri net bir belirleyici faktör değildir. Temel finansal kavramların bilinirliğinin bölüm ve cinsiyete göre farklılaştığı tespit edilmiştir. Özellikle faiz ve kredi kartı gibi finansal kavramların kadın öğrenciler arasındaki ortalama bilinirlik düzeyinin daha yüksek olduğu görülmüştür.

\section{Kaynakça}

Allgood, S., Walstad, W. B. (2013). The Effects of Perceived and Actual FinancialLiteracy on Financial Behaviors. National Financial Capability Study Roundtable, The George Washington School of Business.

Atkinson, A., Messy, F. (2012). Measuring Financial Literacy: Results of the OECD /International Network on Financial Education (INFE) Pilot Study, OECD Working Papers on Finance, Insurance and Private Pensions, No. 15, OECD Publishing. 
Bayram, S. (2010). Finansal Okuryazarlı ve Para Yönetimi Davranışlarl: Anadolu Üniversitesi Öğrencileri Üzerine Uygulama. Yüksek Lisans Tezi, Anadolu Üniversitesi, Eskişehir.

Boz, H. (2019). Risk and Control in Consumer Behavior: A Discussion. In Contemporary Issues in Behavioral Finance. Emerald Publishing Limited (pp.1-12).

Cameron, M. P., Calderwood, R., Cox, A., Lim, S., Yamaoka, M. (2013). Factors Associated with Financial Literacy among High School, Department. Hamilton, New Zealand: Department of Economics, University of Waikato

Chen, H., \& Volpe, R. P. (1998). An analysis of personal financial literacy among college students. Financial services review, 7(2), 107-128.

Chinen, K., Endo, H. (2012), Effects Of Attitude And Background On Personal Financial Ability: A Student Survey In The United States, International Journal of Management Vol. 29 N1o. 1 Part 1, England.

Cihangir, M., Ergin, E. (2015). Finansal Okuryazarlığın Temel Düzeyde İncelenmesi: Osmaniye İlinde Ankete Dayalı Bir Araştırma, Akademik Sosyal Araştırmalar Dergisi, 3(13): 492-511.

Clark, R. L., Ambrosio, M. B., Mcdermed, A. A., Sawant, K. (2003). Financial Education and Retirement Savings, Journal: Available at SSRN 390642. 1-44.

Compen, B., De Witte, K., \& Schelfhout, W. (2018). The role of teacher professional development in financial literacy education: A systematic literature review. Educational Research Review.

Coşkun, Y., Demir, S. ve Işık, İ. (2018). Yatırımcı Davranışlarının Davranışsal Finans Açısından İncelenmesi: Nazilli Örneği. Journal of Current Researches on Social Sciences, 8(4), 1-32.

Er, B., Şahin, Y. E., ve Mutlu, M. (2017). Finansal eylem ve finansal okuryazarlık: Üniversite öğrencilerine yönelik bir araştırma. Finans Politik ve Ekonomik Yorumlar, 54(630), 75-88.

Ergün, B., Şahin, A., \& Ergin, E. (2014). Finansal Okuryazarlık: İşletme Bölümü Öğrencileri Üzerine Bir Çalışma. Journal of International Social Research, 7(34).

Gerek S. ve Kurt A.A. (2011). Ekonomi Okuryazarlı̆̆ Ölçeğinin Geçerlik ve Güvenirlik Çalışması, Uludağ Üniversitesi İktisadi ve İdari Bilimler Fakültesi Dergisi, 30/1, 59-73. 
Güler, E. ve Tunahan, H. (2017). Finansal Okuryazarlık: Hane Halkı Üzerine Bir Araştırma. İşletme Bilimi Dergisi, 5(3), 79-104.

Hilgert, M.A., Hogarth, J.M., Beverly, S.G. (2003). Household Financial Management: The Connection between Knowledge and Behavior. Federal Reserve Bulletin, 89 (7): 309-322.

Jorgensen, B. L. (2007). Financial literacy of college students: Parental and peer influences (Doctoral dissertation, Virginia Tech).

Kahraman, Y. E. (2015), Erciyes Üniversitesi Öğrencileri Üzerinde Finansal Okuryazarlık Araştırması, Yüksek Lisans Tezi, Muğla Sitkı Koçman Üniversitesi, Sosyal Bilimler Enstitüsü, Muğla.

Kılıç, Y., Ata, H. A. ve Seyrek, İ. H. (2015). Finansal okuryazarlık: Üniversite öğrencilerine yönelik bir araştırma. Muhasebe ve Finansman Dergisi, (66), 129-150.

Kılıç, Y., Ata, H. A. ve Seyrek, İ. H. (2015). Finansal okuryazarlık: Üniversite öğrencilerine yönelik bir araştırma. Muhasebe ve Finansman Dergisi, (66), 129-150.

Kieschnick, D. A. (2006). Financial Knowledge Levels and Savings Behaviors of Bermudian High School Seniors at Cedar Bridge Academy. Master of Science, Ames Iowa State

University.http://lib.dr.iastate.edu/cgi/viewcontent.cgi $?$ article $=1863 \&$ context $=$ rtd.

Lusardi, A. Mitchell, O. S. (2011). Financial Literacy and Planning: Implications for Retirement Wellbeing. NBER Working Paper No. 17078, National Bureau of Economic Research, Inchttp://www.nber.org/papers/w17078 (erişim tarihi: 02.10.2018).

Lusardi, A. ve Mitchell, O. S. (2014). The economic importance of financial literacy: Theory and evidence. Journal of Economic Literature, 52(1), 5-44. doi:10,1257/jel.52.1.5.

Lusardi, A., Mitchell, O. S. (2009). How Ordinary Consumers Make Complex Economic Decisions: Financial Literacy and Retirement Readiness. NBER Working Paper No. 15350. National Bureau of Economic Research, Inchttp://www.nber.org/papers/w15350 (erişim tarihi: 05.10.2018).

Mandell, L., Klein, L. S. (2007). Motivation and Financial Literacy. Financial Services Review, 16(2): 105-116. 
Mandell, L., Klein, L. S. (2009). The Impact of Financial Literacy Education on Subsequent Financial Behavior. Journal of Financial Counseling and Planning, 20(1): 15-24.

Mason, C. (2003). Conceptualising Financial Literacy - An Ethnographic Study of School Governors, Loughborough University.

Rooij, M., Lusardi, A. ve Alessie, R. (2007). Financial Literacy and Stock Market Participation. NBER Working Paper No. 146, National Bureau of Economic Reserch

Sarıül, H. (2014). A Survey of Financial Literacy Among University Students. Muhasebe ve Finansman Dergisi, 17(64): 207-224.

Sarıgül, H. (2015). Finansal okuryazarlık tutum ve davranış ölçeği: geliştirme, geçerlik ve güvenirlik. Yönetim ve Ekonomi Araştırmaları Dergisi, 13(1): 200-218.

Şahin, M. ve Barış, S. (2017). Finansal Okuryazarlık ve Tasarruf Davranışları: Kamu Çalışanları Üzerine Bir İnceleme. Çankırı Karatekin Üniversitesi IIBFF Dergisi, 7(2), 77-103.

Şantaş, F., Demirgil, B. (2015), Ekonomik Okuryazarlığı Düzeyinin Tespitine İlişkin Bir Araştırma. Akademik Bakış Dergisi, (48): 46-60.

Temizel, F. (2010). Mavi Yakalılarda Finansal Okuryazarlık. İstanbul: Beta Yayıncılık.

Varcoe, K. P., Martin, A., Devitto, Z. ve Go, C. (2005), Using A Financial Education Curriculum For Teens. Financial Counseling and Planning, 16 (1):63-71.

Vitt, L. A., Reichbach, G.M., Kent, J.L. ve Siegenthaler J.K. (2005). Goodbye to Complacency: Financial Literacy Education İn The Us. 2000- 2005, Insitute for Socio Financial Studies, Middleburg, USA.

Volpe, R. P., Chen, H., \& Liu, S. (2006). An analysis of the importance of personal finance topics and the level of knowledge possessed by working adults. Financial services review, 15(1), 81.

Volpe, R. P., Chen, H., \& Pavlicko, J. J. (1996). Personal investment literacy among college students: A survey. Financial Practice and Education, 6(2), 86-94.

Willis, L. E. (2008). Against Financial-Literacy Education. Iowa Law Review, 94(1).

\section{Internet Sitesi Kaynakları}

foy.tbb.org.tr/turkiye-de-foy Erişim:25.08.2019

https://www.oecd.org/daf/fin/financial-education/OECD-INFE-International-Survey-ofAdult-Financial-Literacy-Competencies.pdf (Erişim:25.08.2019) 


\section{EKLER}

Ek 1: Finansal okuryazarlık ölçeği faktör yükleri (2. Analiz)

\begin{tabular}{|c|c|c|c|}
\hline & \multicolumn{3}{|c|}{ Faktörler } \\
\hline & Tutum & AlgI & Harcama \\
\hline $\begin{array}{l}\text { Alışveriş yaparken aynı ürünün farklı } \\
\text { fiyatlarını kıyaslarım. }\end{array}$ & ,781 &, 184 & ,038 \\
\hline $\begin{array}{l}\text { Bir şey satın alırken maddi } \\
\text { durumumu dikkate alırım. }\end{array}$ & ,770 & ,258 &, 105 \\
\hline $\begin{array}{c}\text { Planlanmamış harcamalar için } \\
\text { kenarda her zaman para } \\
\text { bulundurulmalıdır. }\end{array}$ & ,751 & ,265 &,- 071 \\
\hline $\begin{array}{c}\text { Finans konularında eğitim almak } \\
\text { isterim. }\end{array}$ &, 559 &,- 101 &, 130 \\
\hline Para ile ilgili konular karmaşıktır. & ,489 &,- 196 &,- 288 \\
\hline $\begin{array}{c}\text { Finansal planlama ve bütçe çok } \\
\text { parası olanlar için gereklidir. }\end{array}$ &,- 141 & ,715 & 055 \\
\hline $\begin{array}{l}\text { Günlük ve haftalık gibi kısa } \\
\text { dönemler için harcama planı yapmak } \\
\text { gereksizdir. }\end{array}$ & 275 & ,683 & ,089 \\
\hline $\begin{array}{l}\text { Ne yaparsam yapayım parasal } \\
\text { durumum ne artar ne de azalır. } \\
\text { Değiştiremem. }\end{array}$ & ,217 & ,669 &, 163 \\
\hline $\begin{array}{l}\text { Harcamalarımı kontrol etmekte } \\
\text { zorlanırım. }\end{array}$ &, 034 &, 188 & ,777 \\
\hline Paramın nasıl bittiğini anlamam. &,- 135 & , 152 & ,761 \\
\hline $\begin{array}{c}\text { Haftalık ve aylık harcama planları } \\
\text { yaparım. }\end{array}$ & ,281 &,- 320 & ,472 \\
\hline $\begin{array}{l}\text { Para harcanmak içindir, } \\
\text { biriktirmek için değil. }\end{array}$ &, 101 &, 430 & ,433 \\
\hline
\end{tabular}


Ek 2: Finansal okuryazarlık ölçeği faktör yükleri (3. Analiz)

\begin{tabular}{|c|c|c|c|}
\hline & \multicolumn{3}{|c|}{ Faktörler (Cronbach's Alpha=0,646) } \\
\hline & $\begin{array}{c}\text { Tutum } \\
\text { (Cronbach's } \\
\text { alpha }=0,759)\end{array}$ & $\begin{array}{c}\text { Algı } \\
\text { (Cronbach's } \\
\text { alpha }=\mathbf{0 , 6 1 7 )}\end{array}$ & $\begin{array}{c}\text { Harcama } \\
\text { (Cronbach's } \\
\text { alpha }=\mathbf{0 , 6 4 4 )}\end{array}$ \\
\hline $\begin{array}{l}\text { Alışveriş yaparken aynı ürünün farklı } \\
\text { fiyatlarını kıyaslarım. }\end{array}$ & ,806 &, 161 &,- 041 \\
\hline $\begin{array}{l}\text { Bir şey satın alırken maddi } \\
\text { durumumu dikkate alırım. }\end{array}$ & ,804 & ,211 &, 040 \\
\hline $\begin{array}{c}\text { Planlanmamış harcamalar için } \\
\text { kenarda her zaman para } \\
\text { bulundurulmalıdır. }\end{array}$ & ,739 & ,242 &,- 078 \\
\hline $\begin{array}{c}\text { Finans konularında eğitim almak } \\
\text { isterim. }\end{array}$ & ,647 &,- 229 &, 137 \\
\hline $\begin{array}{c}\text { Finansal planlama ve bütçe çok } \\
\text { parası olanlar için gereklidir. }\end{array}$ &,- 124 & ,752 & ,064 \\
\hline $\begin{array}{l}\text { Günlük ve haftalık gibi kısa } \\
\text { dönemler için harcama planı yapmak } \\
\text { gereksizdir. }\end{array}$ &, 267 & ,731 & , 082 \\
\hline $\begin{array}{l}\text { Ne yaparsam yapayım parasal } \\
\text { durumum ne artar ne de azalır. } \\
\text { Değiştiremem. }\end{array}$ & ,253 & ,666 & ,200 \\
\hline Paramın nasıl bittiğini anlamam. &,- 088 & ,111 & ,854 \\
\hline $\begin{array}{l}\text { Harcamalarımı kontrol etmekte } \\
\text { zorlanırım. }\end{array}$ &, 110 &, 141 & ,831 \\
\hline
\end{tabular}

Ek 3: Açıklanan Varyans

\begin{tabular}{|c|c|c|c|}
\hline Faktörler & Toplam & Varyansin \% & Kümülatif \% \\
\hline 1 & 2,856 & 31,733 & 31,733 \\
\hline 2 & 1,700 & 18,893 & 50,625 \\
\hline 3 & 1,128 & 12,531 & $\mathbf{6 3 , 1 5 6}$ \\
\hline
\end{tabular}

Ek 4: KMO Örneklem Uygunluğu ve Barlett Küresellik Testi

\begin{tabular}{|l|l|r|}
\hline Kaiser-Meyer-Olkin Measure of Sampling Adequacy. &, 760 \\
\hline Bartlett's Test of Sphericity & Approx. Chi-Square & 1317,728 \\
\cline { 2 - 3 } & df & 91 \\
\cline { 2 - 3 } & Sig. &, 000 \\
\hline
\end{tabular}




\section{Ek 5: Baba Eğitim Düzeyi Finansal Okuryazarlık İlişkisi}

\begin{tabular}{|c|c|c|c|c|}
\hline $\begin{array}{l}\text { Bağımlı } \\
\text { Değişken }\end{array}$ & $\begin{array}{l}\text { Babanızın eğitim } \\
\text { düzeyi }\end{array}$ & Babanızın eğitim düzeyi & Std. Hata & $p$ \\
\hline \multirow{12}{*}{ Alg1 Puanı } & \multirow{3}{*}{ Okuryazar değil } & İlköğretim & ,714 & 206 \\
\hline & & Lise & ,727 & ,081 \\
\hline & & Üniversite & ,754 &, 166 \\
\hline & \multirow{3}{*}{ İlköğretim } & Okuryazar değil &, 714 & 206 \\
\hline & & Lise & ,236 & ,481 \\
\hline & & Üniversite & ,308 & ,955 \\
\hline & \multirow{3}{*}{ Lise } & Okuryazar değil & ,727 & ,081 \\
\hline & & İlköğretim & ,236 & ,481 \\
\hline & & Üniversite & ,338 & ,953 \\
\hline & \multirow{3}{*}{ Üniversite } & Okuryazar değil &, 754 & ,166 \\
\hline & & İlköğretim & ,308 & ,955 \\
\hline & & Lise & ,338 & ,953 \\
\hline
\end{tabular}

